\title{
Stone marten (Martes foina) habitat in a Mediterranean ecosystem: effects of scale, sex, and interspecific interactions
}

\author{
Maria João Santos • Margarida Santos-Reis
}

Received: 6 April 2009 /Revised: 11 August 2009/Accepted: 12 August 2009 /Published online: 2 September 2009

(C) The Author(s) 2009. This article is published with open access at Springerlink.com

\begin{abstract}
Mediterranean ecosystems are inherently patchy, challenging habitat-use behavior. Certain mammalian carnivores take advantage of this patchiness by a strategy of habitat complementation/supplementation, which is invariant to the scale of analysis. To test if the same behavior is adopted by the stone marten, we used a combined data set of capture and radio-tracking data at three scales of analysis (1-m, 25-m, and 452-m radius plots). We used compositional analysis to test if there were sex-specific differences in foraging and resting habitat use of stone martens and if these patterns were affected by the presence of other mesocarnivores. Our results showed that stone martens are found both in rural and forested landscapes. Foraging and resting activities occurred far from roads in large and complex patches of cork oak woodlands, riparian vegetation, orchards, and pastureland. Use varied with the scale of analysis and the sex. At smaller scales, females use pastures for foraging and orchards for resting, whereas riparian vegetation and sparse cork oak forests influenced this use at larger scales. Males, on the other hand, were more consistent across
\end{abstract}

Communicated by W. Lutz

M. J. Santos $\cdot$ M. Santos-Reis

Faculty of Sciences, Center of Environmental Biology/

Department of Animal Biology, University of Lisbon,

Ed. C2 $3^{\circ}$ Piso, Campo Grande,

1749-016 Lisboa, Portugal

\section{J. Santos ( $\bowtie)$}

Department of Land, Air, and Water Resources,

University of California, Davis,

The Barn, One Shields Avenue,

Davis, CA 95616, USA

e-mail: mjsantos@ucdavis.edu scales, using riparian areas and dense cork oak woodlands for foraging and pastures for resting. Stone martens shared the same areas with other coexisting mesocarnivores. Stone martens use cork oak woodlands and complement/ supplement this use with other land cover types. The consistent use of cork oak woodlands across scales emphasizes the importance of this land cover to the preservation of functional Mediterranean ecosystems in southern Portugal.

Keywords Compositional analysis · Cork oak woodlands . Mechanisms $\cdot$ Mesocarnivores $\cdot$ Rural interface $\cdot$ Scale

\section{Introduction}

Landscapes provide the ecological template for the life history and behavioral processes that determine animal spacing patterns (Gough and Rushton 2000) and their habitat. Habitat is often defined as a place that provides resources (food, shelter, mate, and den sites) enhancing species' fitness (Morrison et al. 1998), and species express their perception of the landscape and its attributes by their habitat-use patterns (Wiens 1976). Habitat specialists exhibit a behavior that shows a high dependence on particular resources and strong sensitivity to habitat changes and loss. On the other hand, habitat generalists are very plastic, able to survive in many habitats. However, animals' habitat-use strategies are also dictated by constraints of the environments they live in.

Mediterranean ecosystems are inherently heterogeneous due to a legacy of human alterations to the landscape and climate variability (Blondel 2006; Joffre et al. 1999; Pinto-Correia 1993). Wildlife responses to this variability result in a strategy of complementation/supplementation 
use of multiple resources provided by each land cover (Dunning et al. 1992; Herrera 1998; Swihart et al. 2001; Virgós et al. 1999), with a net increase in individual fitness (Bryant 1973). For example, Eurasian badgers (Meles meles) complement resource use by tracking the availability of seasonal food resources (Loureiro et al. 2009; Virgós 2002), and follow a similar pattern spatially for habitat use, in its broader sense (Rosalino et al. 2004; Rosalino et al. 2007; Santos 2003; Virgós 2002). Virgós et al. (2000) indicated the importance of mosaic habitats for stone martens (Martes foina) as compared to pure forest habitats, and similar patterns were observed in other Mediterranean areas (Rondinini and Boitani 2002; Sacchi and Meriggi 1995). Stone martens are native to the Iberian Peninsula (Dobson 1998) and may have adapted to respond to the long history of management practices in these systems (Joffre et al. 1999), which in turn shaped their habitat-use patterns.

Alternatively, the presence of competitors may restrict stone marten's habitat selection. When in sympatry with the pine marten (Martes martes), the stone marten is a habitat generalist with synantropic behavior (use of human structures; Delibes 1983; Herrman 1994; Reig 1992). In areas of the Iberian Peninsula without pine martens (Matos and Santos-Reis 2006), stone martens are known to occupy the higher quality forest habitat (Virgós and Garcia 2002; Virgós et al. 2000). Nonetheless, competition between the stone marten and cooccurring ecologically similar nonnative carnivores, such as the common genet (Genetta genetta) and the Egyptian mongoose (Herpestes ichneumon), may have an effect similar to that of the pine marten. The genet and the mongoose are introduced species to the Iberian Peninsula (Dobson 1998; Gippoliti and Amori 2006) that have been present in this area long enough ( $>200$ years) to develop competitive relationships with other species. It has been shown that competition can develop in only a few years, for example, from introductions of cats to islands (Courchamp et al. 1999) and the American mink (Mustela vison) to wherever the latter has been introduced (Bonesi et al. 2004; Sidorovich et al. 1999).

Species' habitat-use patterns can be affected by the sex of individuals being studied and the scale of the analysis. Mammals in scarce-food environments have reduced bodysize growth, which can lead to sexual dimorphism (Isaac 2005) or it may be expressed in behavioral differences between the sexes. For example, food-niche partitioning between male and female pine martens is dependent on the environmental context (Zalewski 2007); however, this behavioral difference may be attenuated in a heterogeneous environment (Pereboom et al. 2008). Nonetheless, these patterns of habitat use can be affected by the scale of analysis. Animals are known to use habitats differently at different scales (Johnson 1980), which reflect patterns of use at the individual, population, and species' level (Bissonette
1997). However, not all species and environments are conducive to scale effects, and scale effects are greatly affected by landscape spatial heterogeneity (Schooley 2006; $\mathrm{Wu}$ 2004), such as that found in Mediterranean ecosystems. For example, it has been previously shown that habitat selection by European badgers in these regions is not affected by scale (Rosalino et al. 2007; Santos and Beier 2008). Although there is little known about the effect of scale in stone marten's habitat selection (Virgós and Garcia 2002). Martes species are known to be greatly affected by habitat fragmentation, and thus, multiscale approaches have been recommended (Bissonette and Broekhuizen 1995).

Thus, to understand the patterns of stone marten's habitat use in Mediterranean ecosystems at multiple scales, we used capture and radio-tracking data in southern Portugal. More specifically we ask: (1) What is the pattern of habitat use of stone martens in Mediterranean ecosystems?; (2) Which habitats are more often used by stone martens, and do they differ during foraging or resting activities or between sexes?; (3) Is there an effect of scale in habitatuse patterns?; and (4) Is stone marten's habitat use constrained by the presence of other mesocarnivores? Our results will clarify the association of stone marten with human presence and can help to establish goals for future management of the Mediterranean ecosystems in Portugal.

\section{Materials and methods}

\section{Study area}

This study was conducted from 1997 to 2000 , in a $20-\mathrm{km}^{2}$ area in Serra de Grândola (Alentejo, Portugal; Fig. 1). The region is characterized by a matrix of cork oak (Quercus suber) woodland, with patches of holm oak woodland $(Q$. ilex sub-spp. rotundifolia), pastures, Tasmanian blue gum plantations (Eucalyptus globulus), riparian vegetation (dominated by alder Alnus glutinosa, Elm (Ulmus spp.), blackberries (Rubus ulmifolius), orchards (mainly pears, Pyrus bourgeana), figs (Ficus carica), loquats (Eriobrotya japonica), and urban areas. This semi-natural landscape, named montado, has persisted for about 1,300 years (Joffre et al. 1999) and occupies about $36 \%$ of the area of Portugal, mainly in the south, where three main rural activities (cork/ wood-gathering, livestock production, and agriculture) are pursued in a single space. Topography of the region is moderate, with gentle slopes and low altitude (159 to $238 \mathrm{~m}$ ). Climate is Mediterranean with Atlantic influence, with mean annual precipitation levels of $500 \mathrm{~mm}$ (Santos-Reis and Correia 1999). One temporary stream-Castelhanos - runs in the eastern border of the study area. Human activity in the study area is concentrated in one small village - Santa Margarida da Serra - and several isolated farmhouses, but their effects 


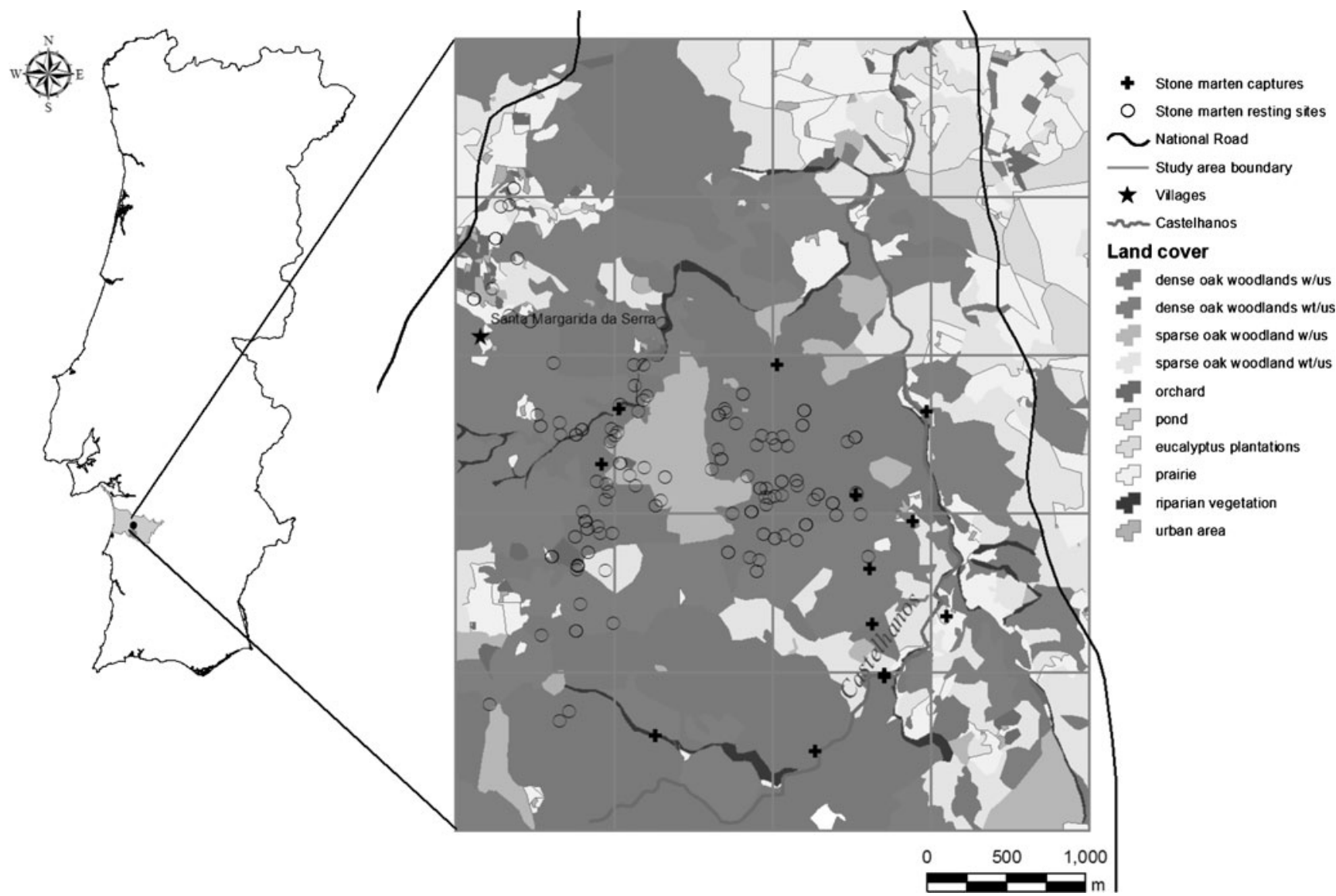

Fig. 1 Location of study area in the Alentejo region of southern Portugal. Study area is $20-\mathrm{km}^{2}$ and includes a small village (Santa Margarida da Serra), several farmhouses (in grey), and one

are extended to the areas where cork and livestock are produced, hunting areas, and timber-producing stands.

\section{Stone marten field data}

Stone martens are mainly nocturnal, spending most of their active time in foraging activities, and being inactive during the day (Delibes 1983; Herrman 1994). These two types of activities may result in very different habitat use patterns. We used radio-tracking data for resting locations and capture data to describe foraging locations. Trapping locations are in essence similar to locations of cameratraps and other type of noninvasive methods for detection of carnivores (for example, scent stations, track plates, and hair snares), and have been extensively used to infer habitat use (Barea-Azcón et al. 2007; Virgós and Garcia 2002). However, trapping data cannot be used to infer patterns of habitat use for resting sites, which requires the high precision and accuracy of locations determined by radiotracking homing techniques (Palomares and Delibes 1992; White and Garrot 1990). We used a $1 \times 1 \mathrm{~km}^{2}$ cell grid to distribute the traps equally throughout the study area, and intermittent stream (Castelhanos). Roads are represented by black lines

placed two box-traps (Tomahawk Live Trap Co., Wisconsin, USA) per grid cell to reduce unequal spacing between traps. This grid size was selected to match the home-range size of a stone marten female (Barea-Azcón et al. 2007; Santos-Reis et al. 2004). One potential confounding factor is the location of the trapping devices. A posteriori, we tested for random distribution of trap locations $\left(R_{\text {traps }}=1.15,|z|=7.14, n=270\right)$ and confirmed a uniform distribution of trapping locations, which therefore should not bias individual's access to the traps.

Traps were set during the nonhunting season (March until August) from 1997 to 2000, baited with sardines in oil, and checked every day in the morning. Animals were anesthetized and measured. Individual marks were given to each animal (combination of cuts in nonregrowing ear tissue) and, after recovery from anesthesia, animals were released in the same site where captured (for details see Rosalino et al. 2005). Three male and two female stone martens, captured in 1997 and 1998, were equipped with radio-transmitters (MOD-080; Telonics Inc., Arizona, USA). Additionally, three males and two female genets were also equipped with radio-collars to address potential 
competition with stone martens. Animals were radiotracked and located at their resting sites every day during each field campaign of 15 days per month in 1997 and 1998 (Santos-Reis et al. 2004). We assume no location error in these locations since individual resting sites (tree, shrub, house structure, etc.) were identified by walking towards the maximum radio-signal intensity and Global Positioning System locations were recorded at the individual tree/shrub. Often stone martens and genets were spotted in tree cavities and tree use was confirmed.

Stone marten's habitat data

Stone martens are habitat generalists (Delibes 1983; Herrman 1994); in Mediterranean ecosystems, they use heterogeneous landscapes with varying configurations (Rondinini and Boitani 2002; Sacchi and Meriggi 1995; Virgós and Garcia 2002; Virgós et al. 2000). To determine landscape composition, we used true-color aerial photography of the study area acquired in 1995 (1-m ground resolution). We photointerpreted the imagery into ten land cover classes: dense cork oak woodlands with understory (DCoW; 653.4 ha), dense cork oak woodlands without understory (DCoWt; 536.5 ha), sparse cork oak woodlands with understory (SCoW; 112.3 ha), sparse cork oak woodlands without understory (SCoWt; 288.6 ha), olive yards and orchards (O; 26 ha), riparian vegetation (RV; 33.2 ha), pastures (P; $282.1 \mathrm{ha}$ ), eucalyptus plantations (E; $45.1 \mathrm{ha}$ ), human settlements $(\mathrm{H} ; 18.2 \mathrm{ha})$, and reservoirs (R; 0.4 ha). As a surrogate for landscape heterogeneity, we calculated the landscape Shannon's diversity Index (ShDI) and to assess the consistency of occurrence of the different landscapes we calculated the landscape Shannon Evenness Index (ShEI) (Elkie et al. 1999). To assess if landscape type and patch configuration had an effect on stone marten habitat use, we estimated patch type and area, its spatial configurationmeasured by shape dimension index (SDI) and tortuositymeasured by the perimeter-area ratio (PAR), and patch fractal dimension (PFD). Finally, to test if stone martens were more often found at the edge of patches or in their interior, we calculated distance to patch edge $(\mathrm{m})$.

Stone martens have also been reported to use riparian ecosystems (Matos et al. 2008; Sacchi and Meriggi 1995; Virgós 2001), and water availability may be a limiting factor in the Mediterranean systems. To assess if proximity to water was a factor contributing to stone marten's habitat use, we estimated the distance to streams from each location. We digitized the hydrological network from available topographic maps $(1: 25,000)$. Stone martens are also affected by road mortality (Ascensão and Mira 2007; Grilo et al. 2008). To assess this effect in stone marten's habitat use, we also estimated the distance of each location to a road (m); using a layer of roads also digitized from the topographic maps
$(1: 25,000)$. All these variables were obtained in ArcView 3.1. and ArcGIS 9 (ESRI, California, USA). Metrics were calculated using Patch Analyst for ArcView (Northwest Science and Technology, Ontario, Canada) and distance variables were calculated using Nearest Features v3.8a for Arcview (Jenness Enterprises, Arizona, USA).

Data reliability assessment

Analysis and interpretation of spatial data may be biased by the presence of spatial autocorrelation (Wagner and Fortin 2005). We used a corrected nearest neighbor algorithm to determine if the foraging and resting locations were randomly distributed (Clark and Evans 1954). This algorithm calculates an adapted correlation coefficient $(R)$, and compares it with normal distribution $z$ values (Hooge and Eichenlaub 1997). This analysis was performed in Animal Movement SA Version 2 for Arcview (USGS-BRD, Alaska, USA). Nearest neighbor analyses resulted in clumped patterns for both capture $\left(R_{\text {capture }}=0.486,|z|=6.07, n=38\right.$, reject $\left.\mathrm{H}_{0}\right)$ and resting locations data $\left(R_{\text {resting }}=0.794,|z|=\right.$ $6.71, n=289$, reject $\mathrm{H}_{0}$ ), indicating that the pattern was mostly due to ecological characteristics rather than the locations themselves.

Since the locations were clumped, we conducted further tests to determine the strength of the spatial autocorrelation. We computed Moran's I index for spatial autocorrelation (Moran 1950) for both foraging and resting locations. Moran's I index varies from -1 (perfect negative spatial autocorrelation) to 1 (perfect positive spatial autocorrelation), with values close to 0 representing no spatial autocorrelation. This statistic allows estimating at which distance spatial autocorrelation occurs and to determine a threshold of lag distance where spatial autocorrelation is negligible. We measured cumulative spatial autocorrelation for lag distances of 25 and $452 \mathrm{~m}$, with a maximum search distance of $1,500 \mathrm{~m}$. These lag distances were selected accordingly for buffer radii in further analyses (see section Data analysis - habitat use). Spatial autocorrelation was calculated using ROOKCASE Microsoft Excel Add-in (Sawada 1999). Moran's I values indicated that for capture data, there was a strong autocorrelation at distances below $100 \mathrm{~m}$, and no significant autocorrelation was observed for resting locations. Because of the clustering pattern of the capture locations, we selected a distance of $>100 \mathrm{~m}$ as the threshold for further analyses. Once spatial distribution patterns were estimated and accounted for, we could proceed in testing our habitat use hypotheses.

Data analysis—-habitat use

We used data from both resting and foraging locations and analyzed habitat use behavior at three different scales of 
analysis: point- (1), 25-, and 452-m radius buffers. The first scale (point) was selected to detect within patch differences in landscape composition and structure of used and nonused patches. For the other two scales of analysis, we surveyed a varying plot size for the composite of landscape units and habitat characteristics being used by stone martens. We used a $25-\mathrm{m}$ radius plot because it represents the individual perception range (Virgós and Garcia 2002), and for the third scale of analysis, we assumed the daily home-range area of radio-tracked males and females as the minimum area needed to obtain daily energy requirements. Concerns of pseudo-replication can be raised that by partitioning radio-tracking data from one individual into daily home-ranges results in nonindependent and inflated sample sizes. However, we believe that this approach is reasonable since we are using the daily home-ranges to inform the buffer size at which to perform the analysis, an alternative to ecologically irrelevant or subjective buffer dimension definition. Daily activity home-range sizes were calculated using Mean Convex Polygon estimator (Mohr 1947) in Animal Movement SA Version 2 for Arcview (USGS-BRD, Alaska, USA). We tested for sex differences in area sizes using analysis of variance (ANOVA). Since there were no significant differences in daily activity homerange sizes of males and females $(F=0.554, p=0.162)$, we considered the average area of $0.64 \mathrm{~km}^{2}$ for buffering, which corresponds to a radius of $452-\mathrm{m}$.

Once the appropriate scales were determined, we wanted to test if habitat for foraging and resting sites was different from random. We derived two sets of random points as pseudoabsence data for foraging and resting sites. Random points were generated within the total study area using an automated software that generates random locations. The number of points was determined by the sample size of either resting or foraging locations. Random points were derived using Random Point Generator v.1.27 for Arcview (ESRI, California, USA). For both stone marten locations and random sites at each scale (point, 25, and $452 \mathrm{~m}$ ), landscape-structure variables (patch structure, distance to edge, roads, and water) were tested for normality with Kolmogorov-Smirnov tests and transformed accordingly (Zar 1999). When normality was not attained, nonparametric procedures were used. Using this suite of variables, we tested if habitat use patterns and landscape structure at these three scales of analysis were different from random using ANOVA, Mann-Whitney and Kruskal-Wallis tests (Zar 1999).

To assess if stone martens have preferential use between forests and rural environments, we considered a habitat as rural if the stone marten location was at $<100 \mathrm{~m}$ from a farmhouse or village. We pooled all data from resting and foraging locations and compared the spatial distribution of forest versus rural environments using ANOVA (Zar 1999).
To test if the stone martens have habitat generalism, if they used complementary habitats and if there were sexand activity-specific habitat use patterns, we used compositional analysis (Aebischer et al. 1993) within the 25- and 452-m buffers. This method compares the proportions of land cover composing a used site with the availability of those land-cover units in the whole study area, providing a gradient selection of the suite of land covers being tested. Proportions of land cover within the 25- and 452-m radius buffers and available in the study area were derived from the land-cover data layers in ArcView. We used Resource Selection for Windows (Fred Leban, University of Idaho, Moscow, USA) software for the analysis, because it does not require large sample sizes, evaluates resource selection among identifiable used areas, and conducts multiple comparisons.

Finally, to test if stone marten's habitat use was affected by the presence of genets and mongooses, we determined if the three species were captured in the same locations. This would indicate if different species are being captured in different habitats. We also determined the frequency of resting sites being shared between individuals, and the average distance between species' locations. This would indicate if the species are found in close proximity during resting or if they constrain resting site selection. Finally, we estimated the overlap between stone martens' and genets' home ranges. We calculated home range for each radio-tagged individual using the kernel method for both the entire home range $(95 \%$ of the locations) and the area of maximum activity $(50 \%$ of the locations) (Worton 1989). This would indicate any patterns of spatial segregation between the species.

All statistical procedures were performed in SPSS 13 for Windows - evaluation version (SPSS Inc., Illinois, USA). All tests were done using the significance level $\alpha=0.05$; the Bonferroni correction was applied to adjust $p$ value levels for multiple comparisons.

\section{Results}

The capture/recapture program resulted in 150 captured animals (46 stone martens, 49 genets, and 55 mongooses) over the 4 years of study. We captured 78 females $(22$ stone martens, 25 genets, and 31 mongooses) and 72 males (24 stone martens, 24 genets, and 24 mongooses). Stone marten (Mf hereafter) radio-tracking data resulted in 289 resting sites (females: $\mathrm{Mf}_{1}=15, \mathrm{Mf}_{19}=113$; male: $\mathrm{Mf}_{2}=17, \mathrm{Mf}_{17}=$ $\left.56, \mathrm{Mf}_{18}=88\right)$.

Stone marten's habitat use

Stone martens were found both in rural and forested habitats. Stone martens were detected significantly less 
frequently in forested habitats $(25.2 \%)$ than in rural habitats $(74.8 \%)$, both in foraging $\left(\%_{\text {forest }}=7.6, \%_{\text {rural }}=92.4\right)$ and resting periods $\left(\%_{\text {forest }}=28.4, \%_{\text {rural }}=71.6\right)$. Both forest and rural locations showed a clumped spatial distribution $\left(R_{\text {forest }}=0.824,|z|=5.73, n=292\right.$, reject $\mathrm{H}_{0} ; R_{\text {rural }}=0.53$, $|z|=6.49, n=53$, reject $\left.\mathrm{H}_{0}\right)$.

Stone martens were found in a variety of patch sizes of the different land-cover units and used mostly smaller patches $(<5$ ha) of pastures $(n=28)$ and orchards $(n=14)$; the species also used intermediate-sized patches (5-20 ha) of riparian vegetation $(n=18)$; median patches $(20-50$ ha) of both pastures $(n=39)$ and dense cork oak woodland $(n=45)$; and larger patches (50-100 ha) of sparse cork oak woodland $(n=9)$. The larger patches $(>100 \mathrm{ha})$ used by stone martens correspond to dense cork oak woodland both with and without understory $\left(n_{\text {with understorey }}=128 ; n_{\text {without understorey }}=\right.$ 38). Despite the even distribution of landscape units in the study area $(\mathrm{ShEI}=0.845 ; \mathrm{ShDI}=1.947)$, stone martens were more often located in cork oak woodland, with few found in pastureland. Both sexes were using mostly large patches of dense cork oak woodlands for both foraging $\left(n_{\text {males }}=17\right.$; $\left.n_{\text {females }}=16\right)$ and resting $\left(n_{\text {males }}=72 ; n_{\text {females }}=75\right)$, with males also resting in sites with small patches of pastureland $(n=70)$, and females in riparian vegetation $(n=10)$ and orchards $(n=14)$.

Stone martens' activity- and sex-specific habitat use

Foraging and resting sites were different from random sites; both were influenced by distance to roads, streams, and shape index and fractal dimension. We found significant positive influences of distance to roads, shape dimension index, and patch fractal dimension for both resting and foraging comparisons (Table 1). Resting sites were also positively influenced by distance to water, whereas foraging sites had a negative association with this variable (Table 1).

Male resting sites were closer to roads and farther from streams than those of females, whereas no significant differences were found in foraging sites. Significant sexdifferences were found for resting sites in distance to roads $\left(U_{D_{-} \text {roads }}=5439.5, p=0.000\right)$ and distance to streams $\left(U_{\mathrm{D} \_ \text {streams }}=7832.5, p=0.012\right)$. Males rested on average at $923.21 \pm 717.9 \mathrm{~m}$ from roads and $1,512.42 \pm 590.83 \mathrm{~m}$ from streams, where females' resting sites were $1,552.03 \pm$ $204.38 \mathrm{~m}$ from roads and $1,418.24 \pm 413.0 \mathrm{~m}$ from streams.

Scale effect on stone marten's habitat use

Male and female stone martens selected dense cork woodland with understory in foraging and resting time bouts, with the exception of female resting data in 452-m radius plots. We found no differences in sex-specific land cover either in resting or in foraging sites (Table 2).

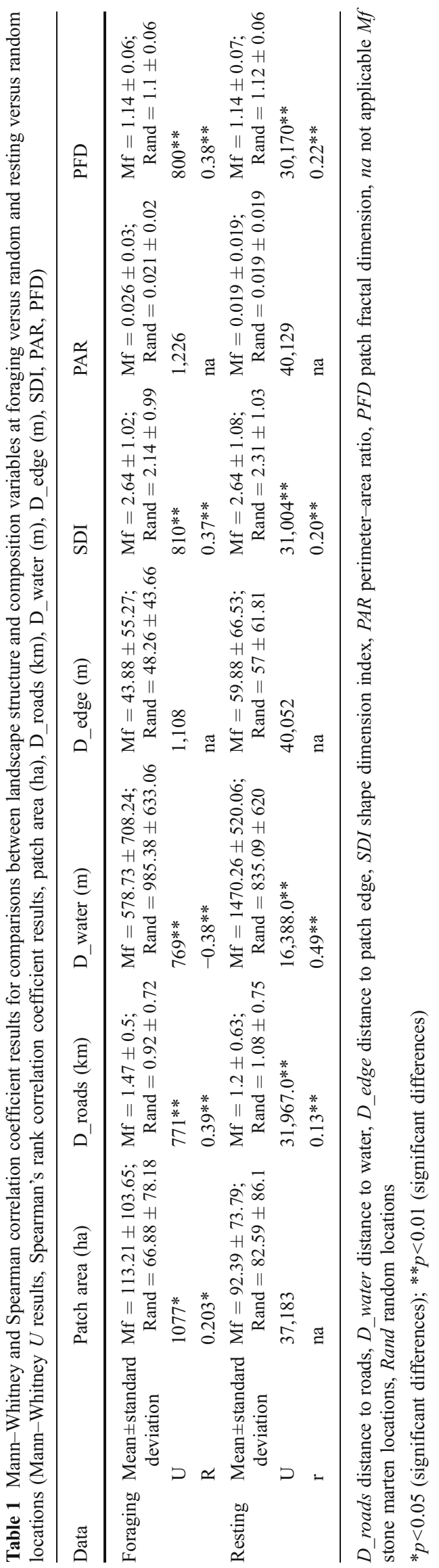


Table 2 Compositional analysis of sex-specific stone marten foraging and resting habitat selection (Aebischer et al. 1993) in the study area

\begin{tabular}{|c|c|c|c|}
\hline Sex & Data & Radius & Compositional analysis \\
\hline \multirow[t]{4}{*}{ Male } & \multirow[t]{2}{*}{ Foraging } & $25 \mathrm{~m}$ & DCoW $>$ RV $>>$ P $>$ O $>$ SCoW $>$ DCoWt $>$ SCoWt $>>$ HS $>>$ R $>>$ E \\
\hline & & $452 \mathrm{~m}$ & DCoW $>>$ DCoWt $>$ RV $>$ SCoW $>$ SCoWt $>$ P $>$ O $>$ HS $>>$ R $>>$ E \\
\hline & \multirow[t]{2}{*}{ Resting } & $25 \mathrm{~m}$ & DCoW $>>\mathrm{P}>\mathrm{O}>\mathrm{RV}>>\mathrm{DCoWt}>\mathrm{SCoW}>>\mathrm{SCoWt}>>\mathrm{HS}>>\mathrm{R}>>\mathrm{E}$ \\
\hline & & $452 \mathrm{~m}$ & DCoW $>>\mathrm{P}>\mathrm{O}>\mathrm{RV}>>\mathrm{DCoWt}>\mathrm{SCoW}>>\mathrm{SCoWt}>>\mathrm{HS}>>\mathrm{R}>>\mathrm{E}$ \\
\hline \multirow[t]{4}{*}{ Female } & \multirow[t]{2}{*}{ Foraging } & $25 \mathrm{~m}$ & DCoW $>>\mathrm{P}>\mathrm{O}>>\mathrm{RV}>>\mathrm{DCoWt}>\mathrm{SCoW}>\mathrm{SCoWt}>>\mathrm{HS}>>\mathrm{R}>>\mathrm{E}$ \\
\hline & & $452 \mathrm{~m}$ & DCoW $>$ RV $>$ DCoWt $>>$ SCoWt $>$ SCoW $>$ P $>$ O $>>$ HS $>>$ R $>>$ E \\
\hline & \multirow[t]{2}{*}{ Resting } & $25 \mathrm{~m}$ & DCoW $>>\mathrm{O}>>$ RV $>$ DCoWt $>$ SCoW $>$ P $>$ SCoWt $>>$ HS $>>$ R $>>$ E \\
\hline & & $452 \mathrm{~m}$ & DCoWt $>$ SCoW $>>$ SCoWt $>$ P $>>$ DCoW $>>$ O $>>$ RV $>>$ HS $>>$ R $>>$ E \\
\hline
\end{tabular}

$H S$ human settlements, $R$ reservoirs, $E$ eucalyptus, $D C o W$ dense cork oak woodland with understorey, DCoWt dense cork oak woodland without understorey, $S \mathrm{CoW}$ sparse cork oak woodland with understorey, SCoWt sparse cork oak woodland without understorey, $O$ orchards, $P$ pastures, $R V$ riparian vegetation, $>$ denotes greater importance of land cover unit, $>>$ denotes significant differences between land cover units

However, there was variability in the second most selected land-cover unit according to the scale at which the analysis was performed. Thus, in $25-\mathrm{m}$ radius plots, males selected mostly riparian vegetation during foraging, whilst females used mostly pastures and orchards. At this scale, both males' and females' resting sites were selected in orchards, with males also using pastureland and females, riparian vegetation (Table 2 ). In the $452-\mathrm{m}$ radius plots, both males and females selected dense cork oak woodlands without understory and riparian vegetation during foraging. Resting site habitat use at this scale was dissimilar to the results from previous analyses. Males selected pastureland, orchards, and riparian vegetation, and females selected sparse cork oak woodlands with and without understory.

Interspecific effects on stone marten's habitat use

There was no spatial segregation in trapping locations between stone martens, genets, and mongooses. Traps were equally visited by any of the three species (Fig. 2). Stone martens and genets shared four resting sites, which were used 23 times by both males and females (Fig. 2). On average, both species were located within $157.8 \mathrm{~m}$ of each other, and female stone martens were on average significantly farther away from genets $(196.9 \mathrm{~m})$ than were male stone martens (108.6 m).

Stone martens were found sharing their home ranges with genets. We measured $60 \%$ overlap between genets and stone martens 95\% kernel home range (310.07 ha), and a $27.6 \%$ overlap between genets and stone martens $50 \%$ kernel home range (29.57 ha; Fig. 3).

\section{Discussion}

Our working hypothesis was that the most important mechanism driving stone marten's habitat use would be habitat complementation rather than competition with other carnivores. The stone martens may have adapted their habitat use behaviors to respond to the long history (13 centuries) of forest management practices in the Mediterranean ecosystems (Joffre et al. 1999) rather than to the presence of exotic species (500 years for the genet and 200 years for the mongoose, Dobson 1998). Our results corroborate this prediction, since stone marten's habitat use behavior is restricted by land cover composition (large and structurally complex patches of cork oak woodlands at any scale of analysis) and presence of anthropogenic structures (roads and houses) rather than interference with other carnivore species. During the survey period, there was clear evidence of sex-specific habitat-use patterns, with females selecting resting sites farther from roads and closer to streams and richer food areas.

\section{Stone marten's habitat use}

Stone martens are found in a variety of habitats throughout the Paleartic range (Dobson 1998; Libois and Waechter 1991). Phenotypic plasticity and local adaptations to available habitats are expected, which makes them habitat generalists (Dobson 1998; Libois and Waechter 1991; Reig 1992). To our knowledge, studies that have addressed stone martens' habitat use in the Iberian Peninsula corroborated the generalist character of the stone marten's habitat use (Santos-Reis et al. 2004; Virgós and Casanovas 1998; Virgós and Garcia 2002; Virgós et al. 2000), and so does our study.

At the local scale of analysis, stone martens in southern Portugal are found in all the available habitats, including forested (25.2\%) and rural habitats (74.8\%). Forested habitats have been identified as key-habitats for other marten species, such as the pine marten, the American marten (Martes americana), and the fisher (Martes pennanti; Harrison et al. 2004). Stone martens 


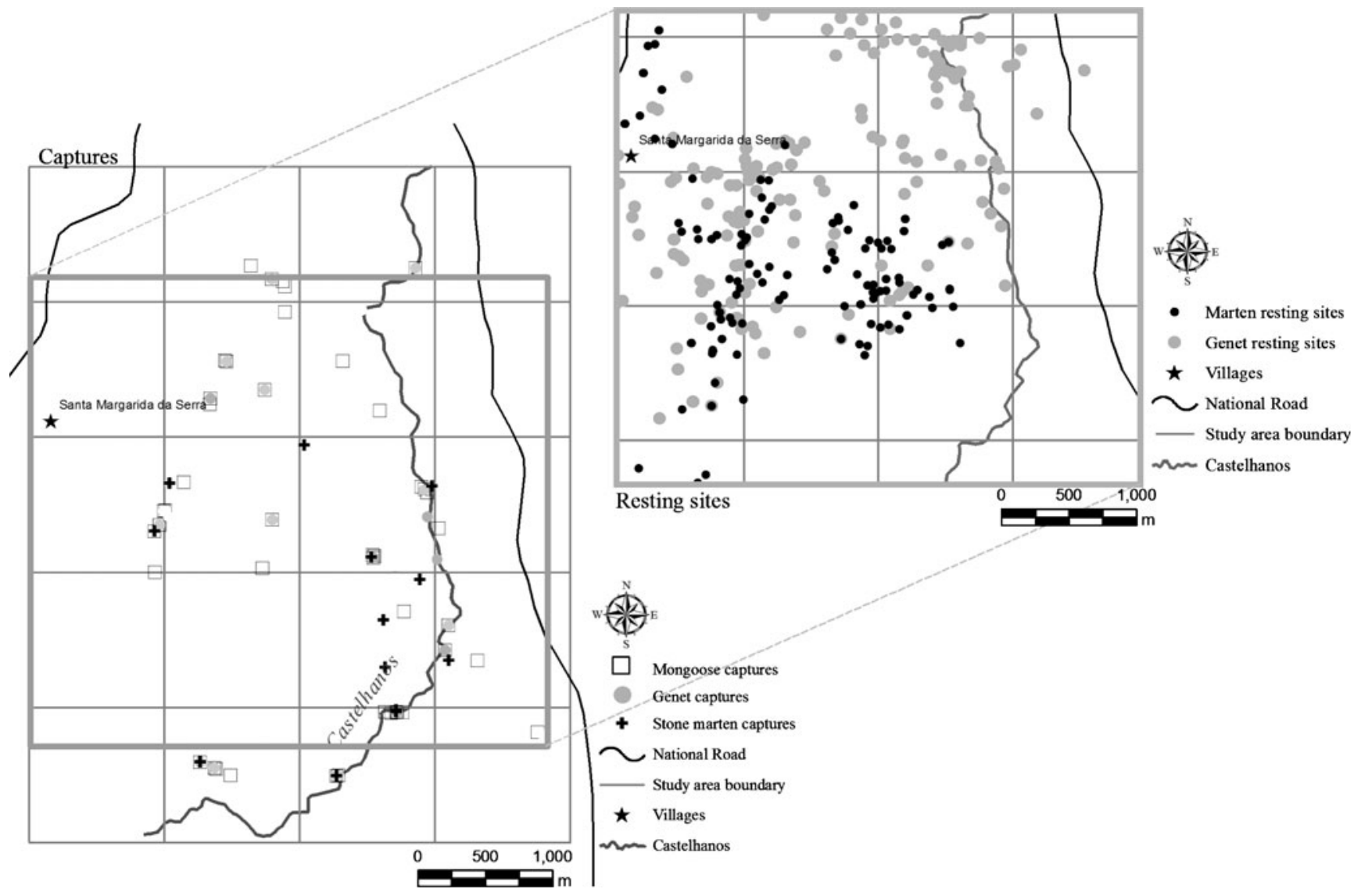

Fig. 2 Foraging (capture) and resting locations for stone martens, genets, and mongooses in the study area

differ from other marten species by having synantrophic behavior and living in European cities such as Nantes, (G. Le Lay, University of Angers, France, personal communication), Budapest (M. Tóth-Apáthy, Eötvös Loránd University, Hungary, personal communication), or Krakow (I. Wierzbowska, Jagiellonian University, Poland, personal communication). However, in Mediterranean ecosystems, urban habitats, when used, can either be complementary with the use of large and contiguous forested habitats (Virgós and Garcia 2002) or used independently (Rondinini and Boitani 2002). In Portugal, they use patches with complex geometric forms with a higher edge, which may indicate a higher accessibility to neighboring patches of complementary habitats.

There was a clear selection for dense cork oak woodlands (Table 2) at all the scales of analysis, activities and sexes. Dense cork oak woodland with understory is the most represented land-cover unit (32.7\%) in the study area. Its selection as a top-ranking unit indicates its role as resting-site provider, shelter during foraging, and foraging grounds. In the study area, it was reported that stone martens use trees and blackberry bushes as main resting sites and abandoned barns and cork piles as alternative resting sites (Pereira and Santos-Reis submitted). Thus, it can be expected that in an area with mean tree density of 120 trees/ha (L. Silva, Parceria Pro-Montado, personal communication), stone martens will use those structures as resting sites according to their availability, and a marked selection will occur towards blackberry bushes, which are only found in $3 \%$ of the study area. The role of dense cork oak woodlands as shelter providers is mediated by the presence of dense understory vegetation, which has been demonstrated as very important for carnivores in Mediterranean ecosystems (Mangas et al. 2008). In our case, shrubs underneath the cork oaks may provide shelter during foraging bouts, and also can be used as resting sites (M. J. Santos, personal observation). Furthermore, the selection of cork oak woodlands may also be related to the availability of food resources. During their activity bouts, stone martens spend most of their time foraging (Herrman 1994) and consuming food items according to their availability, which makes them a feeding generalist (Carvalho and Gomes 2004; Libois and Waechter 1991). In the Mediterranean ecosystems, food resources have seasonal peaks of availability following a pulsed pattern (F. Loureiro, University of Lisbon, personal communication), which may trigger a complementarity/ 


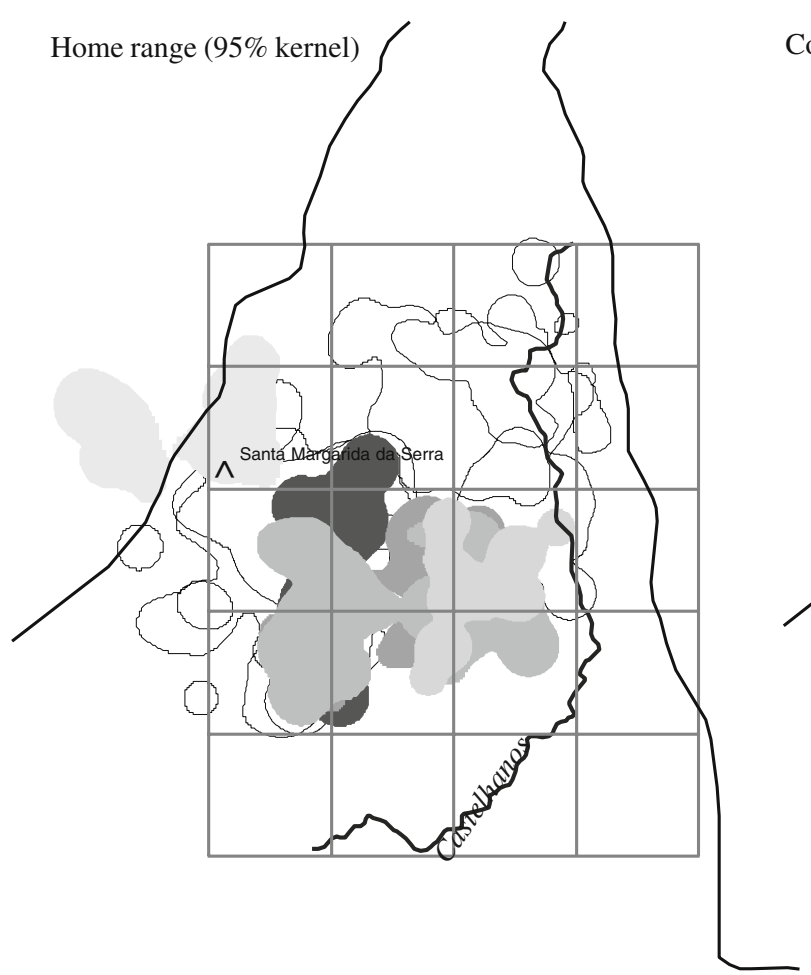

Fig. 3 Home-range (95\% kernel) and core area (50\% kernel) overlap between stone martens and genets in the study area. Grey areas represent stone marten home ranges (left subpanel) and core areas

supplementation strategy (Swihart et al. 2001) or a temporal segregation of food resources (Barrientos and Virgós 2006). In the study area, stone martens exploit these resources, consuming mostly fruits, insects, and small mammals; whereas the first of these can be found in orchards $(1.3 \%$ of the study area), insects and small mammals are mostly available in cork oak woodlands and riparian areas $(1.7 \%$ of the study area; Santos et al. 2007), thus explaining the observed pattern of higher selection of oak woodlands.

Riparian vegetation is also highly selected for by stone martens in the study area. Riparian areas have often been identified as important habitats for wildlife and as movement corridors (Beier and Noss 1998; Matos et al. 2008; Virgós 2001). In the study area, the riparian ecosystems are contained within the matrix of cork oak woodland and the transition between the two land-cover types is not marked by changes in structural components but in species composition. An ongoing study has shown that carnivore species are using the two land-cover types indiscriminately (Matos et al. 2008). Furthermore, higher carnivore richness is observed in a mixed landscape with riparian areas containing sclerophyllous woody plants than in cork oak woodlands alone (M.J. Santos, H. Matos and M. Santos-Reis, unpublished data).

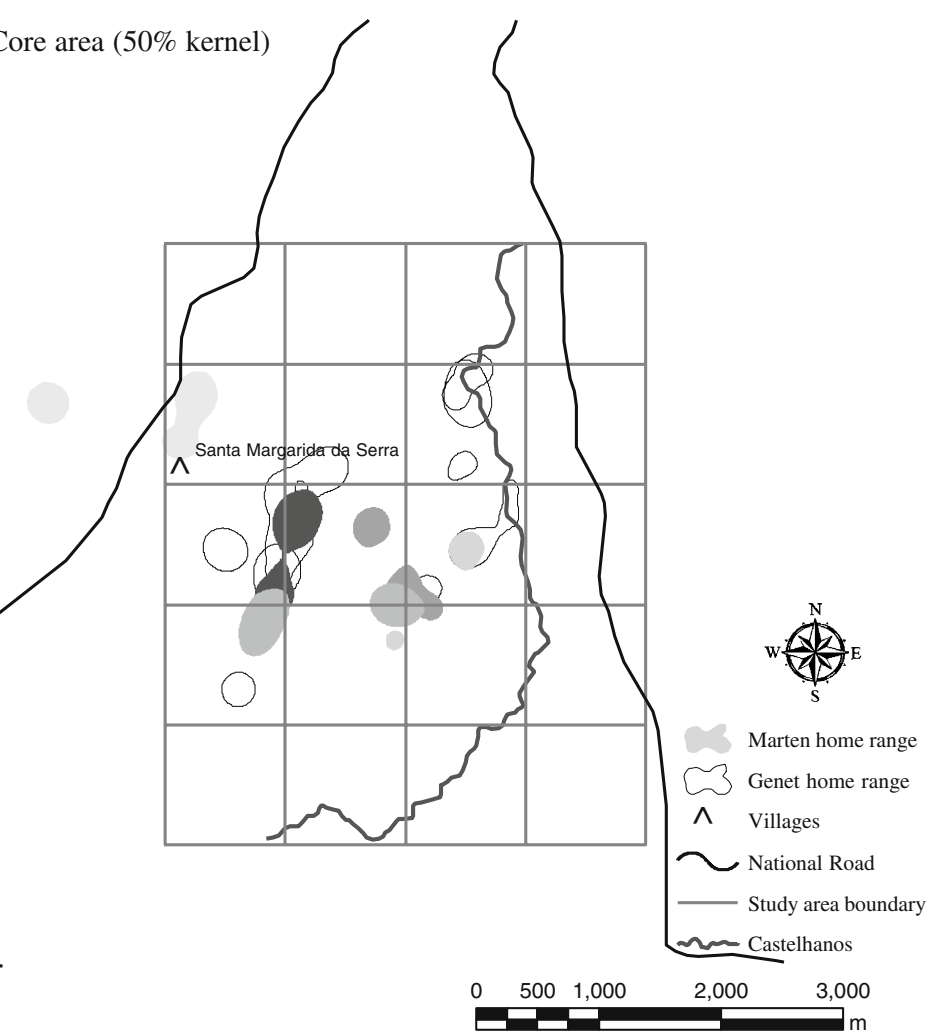

(right subpanel) overlaid on genet home range and core areas in black line (right subpanel home range and left figure core area)

Orchards and pastureland were also selected by stone martens. We believe that the selection of pastures and orchards is associated with a higher availability of feeding resources, orchards providing fruits and insects, and pasturelands, small mammals and insects. Interestingly, pastures have been selected by males as resting sites, which may be explained by the fact that most abandoned barns or cork piles used by stone marten (Pereira and Santos-Reis, submitted) are surrounded by pastureland. In addition, one radio-tracked male had a high resting-site fidelity (revealed by a high reuse rate) to a cork pile located in a pastureland outside the small village of Santa Margarida da Serra (Pereira and Santos-Reis, submitted). Other studies, however, have shown that stone martens avoided pasturelands during their movements, only using them during dispersal movements (Rondinini and Boitani 2002). Perhaps the difference between our study and previous results (Herrman 1994; Rondinini and Boitani 2002) is the size of pastureland habitat, which in our case consisted of small arable areas within the rural settlement.

We found no evidence of an effect of other mesocarnivores on stone marten's habitat use. Stone martens, genets, and mongooses were found in similar locations, and the first two were often detected sharing the same resting site, 
core area, and home range. To our knowledge, this sharing of similar area between stone marten and other species has not frequently been described in the literature (Santos-Reis et al. 2004). However, other authors assessing competition for food resources between stone marten and other species in Mediterranean environments have advanced an explanation that may fit our results (Barrientos and Virgós 2006). These authors suggest that there is exclusive use of key resources and sequential use of shared resources, without intensive exploitation of any of the resources by either of the species (Barrientos and Virgós 2006). This can be applied to our study, as many resting sites are available and there is a low degree of site fidelity (Santos-Reis et al. 2004), and thus, different species can use the same resource or even the same tree sequentially. Further clarification of these results is necessary, and we recommend a study simultaneously radio-tracking these species as well as analyzing their diets.

Stone marten's sex-specific habitat use

Individual fitness is improved by habitat quality (Bryant 1973). Carnivores dedicate most of their reproductive energy to the successful rearing of cubs, which has been identified as the favored life-history trait of stable environments (K-selection-late maturity broods, a few large young, parental care, and small reproductive efforts(Steams 1976)). Theories on sexual reproduction have stated that parental care is highly variable according to species' behavior. In mammals, parental care consists mainly of providing food for offspring (Farmer 2000) and is usually performed by the female (Krebs and Davies 1993). Thus, sex-specific habitat use should favor the female stone marten selecting patches that are less disturbed and richer in food. Our results show both sexes used the same large cork oak woodland patches for foraging and resting. However, differences were found for male and female resting sites. On one hand, females rested in sites farther from roads (less disturbed) and closer to edges (which allows the use of complementary habitats once most resting sites are within the cork woodland matrix), streams (higher water availability), and food-rich areas (riparian vegetation and orchards). On the other hand, males' resting sites were closer to roads (higher disturbance), farther from the edge and streams, and in pastureland (lower cover/ protection, and lower food availability). Thus, there seems to be a pattern of sex-induced habitat segregation in resting sites, which could be a consequence of facilitation by males to females during the reproductive season, in order to increase reproductive success. Males seem to allow females to use better-quality patches of riparian vegetation and orchards, which provide small mammals (Santos et al. 2007) and insects and fruits (F. Loureiro, University of
Lisbon, personal communication), and to share rich resting sites in areas of cork oak woodlands (Pereira and SantosReis submitted).

Scale effect on stone marten's habitat use

Habitat selection occurs at multiple spatial scales (Johnson 1980; Wiens 1989) and can be partitioned into four levels of selection: geographic range, home range, components within the home range, and specific resources at a site; a hierarchy that can be extended to other scales. Besides, different habitat factors may be important at different scales (Bissonette 1997; Wiens 1989). Species-specific responses to fragmentation are related to differences in the perception of landscape structure and the scale at which it occurs (Gehring and Swihart 2003). Perceptual range is dependent on body size, where large-bodied mammals perceive landscapes as more homogeneous than smaller species (Gehring and Swihart 2003). Thus, it can be expected that stone martens would perceive the landscape as heterogeneous at the scales of our study. In fact, our results showed that stone martens were exploiting landscape heterogeneity by selecting complementary landscape units. Analyses conducted at different scales should identify different sets of explanatory variables. In southern Portugal, three studies have already demonstrated a lack of scale effects on European badger habitat selection in the Mediterranean woodlands (Rosalino et al. 2007; Santos 2003; Santos and Beier 2008). Our results showed that stone martens also lack an effect of scale, since at all studied scales, stone martens select dense cork oak woodlands with understory.

Analyses at multiple scales have inherent nested data (Jelinski and Wu 1996). In our study, we considered this effect as negligible, because we have used the same landcover map for all the analyses and photo-interpretation considered the minimum analysis units (trees) as suggested by Jelinski and $\mathrm{Wu}$ (1996), and we did not aggregate polygons, only recalculated percentage of land cover within each plot size (25- and 452-m radius).

\section{Conclusions}

Habitat generalist species presumably can make more complete use of nonmatrix habitats when moving through a fragmented landscape (Gehring and Swihart 2003). Our results show that stone martens have a habitat use pattern that is dependent on cork oak woodlands and this pattern is consistent across scales. This could indicate a forest specialization; however, as other habitats are being used simultaneously with cork oak forests, it suggests a complementation/supplementation strategy. The legacy of the traditional management of cork oak woodlands creates a 
landscape which is composed by mosaics of forest interspersed with orchards, riparian ecosystems, and pastures, which stone martens cross and use. This suggests that future conservation of stone marten populations in cork oak habitats may occur through the maintenance of the inherent spatial heterogeneity of the landscape.

Acknowledgments The present paper was sponsored by the Fundação para Ciência e Tecnologia project "Development of an integrated model for the management of the cork oak woodland" (PRAXIS XXI/PCNA/C/BIA/105/96; MJS: PRAXIS XXI/BTI/14682/ 97). The authors are grateful to Luís Miguel Rosalino, Marina Rodrigues, Sónia Domingos, Bruno Miguel Pinto, Sofia Lourenço, João Tiago Marques, Iris Pereira Caetano, Clara Espírito Santo, Mário Mota, Hugo Costa, Maria João Cruz, Hugo Matos, and Filipa Loureiro with whom the fieldwork was shared; Chantelle Anandan, Margaret Andrew and Pedro Leitão for English language revision. Captured animals were handled following all the recommendations of the Animal Welfare Protocol of the European Union and with the capture permission of the Portuguese Institute for the Nature Conservation.

Open Access This article is distributed under the terms of the Creative Commons Attribution Noncommercial License which permits any noncommercial use, distribution, and reproduction in any medium, provided the original author(s) and source are credited.

\section{References}

Aebischer NJ, Robertson PA, Kenward RE (1993) Compositional analysis of habitat use from animal radio-tracking data. Ecology 74:1313-1325

Ascensão F, Mira A (2007) Factors affecting culvert use by vertebrates along two stretches of road in southern Portugal. Ecol Res 22:57-66

Barea-Azcón JM, Virgós E, Ballesteros-Duperon E, Moleon M, Chirosa M (2007) Surveying carnivores at large spatial scales: a comparison of four broad-applied methods. Biodiv Conserv 16:1213-1230

Barrientos R, Virgós E (2006) Reduction of potential food interference in two sympatric carnivores by sequential use of shared resources. Acta Oecol 30:107-116

Beier P, Noss R (1998) Do habitat corridors provide connectivity? Conserv Biol 12:1241-1252

Bissonette JA (1997) Wildlife and landscape ecology: effects of pattern and scale. New York, USA

Bissonette JA, Broekhuizen S (1995) Martes populations as indicators of habitat spatial patterns: the need for a multiscale approach. In: Lidicker WZ (ed) Landscape approaches in mammalian ecology and conservation. University of Minnesota Press, Saint Paul, p 215

Blondel J (2006) The 'design' of Mediterranean landscapes: a millennial story of humans and ecological systems during the historic period. Hum Ecol 34:713-729

Bonesi L, Chanin P, MacDonald DW (2004) Competition between Eurasian otter Lutra lutra and American mink Mustela vison probed by niche shift. Oikos 106:19-26

Bryant EH (1973) Habitat selection in a variable environment. J Theor Biol 41:421-429

Carvalho JC, Gomes P (2004) Feeding resource partitioning among four sympatric carnivores in the Peneda-Gerês National Park (Portugal). J Zool 263:275-283

Clark PJ, Evans FC (1954) Distance to nearest neighbor as a measure of spatial relationships in populations. Ecology 35:445-453
Courchamp F, Langlais M, Sugihara G (1999) Cats protecting birds: modelling the mesopredator release effect. J Anim Ecol 68:282292

Delibes M (1983) Interspecific competition and the habitat of the stone marten Martes foina (Erxleben, 1777) in Europe. Act Zool Fenn 174:229-231

Dobson M (1998) Mammal distributions in the western Mediterranean: the role of human intervention. Mammal Rev 28:77-88

Dunning JB, Danielson BJ, Pulliam HR (1992) Ecological processes that affect populations in complex landscapes. Oikos 65:169175

Elkie P, Rempel R, Carr A (1999) Patch Analyst User's Manual. Ontario Ministry of Natural Resources Northwest Science and Technology, Thunder Bay, Ontario, Canada

Farmer GC (2000) Parental care: the key to understanding endothermy and other convergent features in birds and mammals. Am Nat 155:326-334

Gehring TM, Swihart RK (2003) Body size, niche breadth, and ecologically scaled responses to habitat fragmentation: mammalian predators in an agricultural landscape. Biol Conserv 109:283-295

Gippoliti S, Amori G (2006) Ancient introductions of mammals in the Mediterranean Basin and their implications for conservation. Mammal Rev 36:37-48

Gough MC, Rushton SP (2000) The application of GIS-modelling to mustelid landscape ecology. Mammal Rev 30:197-216

Grilo C, Bissonette JA, Santos-Reis M (2008) Response of carnivores to existing highway culverts and underpasses: implications for road planning and mitigation. Biodiv Conserv 17:1685-1699

Harrison DJ, Fuller AK, Proulx G (2004) Marten and fishers (Martes) in human-altered environments: an international perspective. Springer, New York

Herrera CM (1998) Long-term dynamics of Mediterranean frugivorous birds and fleshy fruits: a 12-year study. Ecol Monog 68:511-538

Herrman M (1994) Habitat use and spatial organization by the stone marten. In: Buskirk SW, Harestad AS, Raphael MG, Powell RA (eds) Martens, sables and fishers. Cornell University Press, Ithaca, pp 122-136

Hooge PN, Eichenlaub B (1997) Animal movement extension to Arcview version 1.1. Alaska Science Center-Biological Science Office, US Geological Survey, Anchorage, AK, USA

Isaac JL (2005) Potential causes and life-history consequences of sexual dimorphism in mammals. Mammal Rev 35:101-115

Jelinski DE, Wu J (1996) The modifiable areal unit problem and implications for landscape ecology. Lands Ecol 11:129-140

Joffre R, Rambal S, Ratte JP (1999) The dehesa system of southern Spain and Portugal as a natural ecosystem mimic. Agrofor Syst 45:57-79

Johnson D (1980) The comparison of usage and availability measurements for evaluating resource preference. Ecology 61:65-71

Krebs JR, Davies NB (1993) An introduction to behavioural ecology. Blackwell Scientific

Libois R, Waechter A (1991) La Fouine (Martes foina Erxleben, 1777). Société Française pour l'Étude et la Protéction des Mammiféres pp 53

Loureiro F, Bissonette JA, Macdonald DW, Santos-Reis M (2009) Temporal variation in the availability of Mediterranean food resources: do badgers Meles meles track them? Wildl Biol 15:197-206

Mangas JG, Lozano J, Cabezas-Diaz S, Virgos E (2008) The priority value of scrubland habitats for carnivore conservation in Mediterranean ecosystems. Biodiv Conserv 17:43-51

Matos H, Santos-Reis M (2006) Distribution and status of the pine marten Martes martes in Portugal. In: Santos-Reis M, Birks JDS, O'Doherty EC, Proulx G (eds) Martes in carnivore communities. Alpha Wildlife Publications, Sherwood Park, Alberta, Canada 
Matos HM, Santos MJ, Palomares F, Santos-Reis M (2008) Does riparian habitat condition influence mammalian carnivore abundance in Mediterranean ecosystems? Biodiv Conserv 18:373-386

Mohr CO (1947) Table of equivalent population of North American small mammals. Am Midl Nat 3:223-249

Moran PAP (1950) A test for the serial independence of residuals. Biometrika 37:178-181

Morrison ML, Marcot BG, Mannan RW (1998) Wildlife-habitat relationships - concepts and applications. The University of Wisconsin Press, Madison

Palomares F, Delibes M (1992) Circadian activity patterns of freeranging large gray mongooses, Herpestes ichneumon, in southwestern Spain. J Mamm 73:173-177

Pereboom V, Mergey M, Villerette N, Helder R, Gerard J-F, Lode T (2008) Movement patterns, habitat selection, and corridor use of a typical woodland-dweller species, the European pine marten (Martes martes), in fragmented landscape. Can J Zool 86:983-991

Pinto-Correia T (1993) Threatened landscape in Alentejo, Portugal: the 'montado' and other 'agro-silvo-pastoral' systems. Lands Urb Plan 24:43-48

Reig S (1992) Geographic variation in pine marten (Martes martes) and beech marten (M. foina) in Europe. J Mamm 73:744-769

Rondinini C, Boitani L (2002) Habitat use by beech martens in a fragmented landscape. Ecography 25:257-264

Rosalino LM, MacDonald DW, Santos-Reis M (2004) Spatial structure and land-cover use in a low density Mediterranean population of Eurasian badgers. Can J Zool 82:1493-1502

Rosalino LM, Santos MJ, Domingos S, Rodrigues M, Santos-Reis M (2005) Population structure and body size of sympatric carnivores in a Mediterranean landscape of SW Portugal. Rev Biol. (Lisb) 23:135-146

Rosalino LM, Santos MJ, Beier P, Santos-Reis M (2007) Eurasian badger habitat selection in Mediterranean environments: does scale really matter? Mamm Biol 73:189-198

Sacchi O, Meriggi A (1995) Habitat requirements of the stone marten (Martes foina) on the Tyrrhenian slopes of the northern Apennines. Hystrix 7:99-104

Santos MJ (2003) Habitat selection by European badgers at multiple spatial scales: implications for the conservation of the montado. Environmental Sciences and Policy, Northern Arizona University, Flagstaff, p 116

Santos MJ, Beier P (2008) Habitat selection by European badgers at multiple spatial scales in Portuguese Mediterranean ecosystems. Wildl Res 35:835-843

Santos MJ, Pinto BM, Santos-Reis M (2007) Is trophic niche partitioning the solution for the coexistence of carnivores in a Mediterranean landscape of SW Portugal? WebEcology 7:53-62

Santos-Reis M, Correia AI (1999) Caracterização da flora e da fauna do montado da Herdade da Ribeira Abaixo (Grândola - Baixo Alentejo). Lisboa, Portugal

Santos-Reis M, Santos MJ, Lourenco S, Marques JT, Pereira I, Pinto B (2004) Relationships between stone martens, genets and cork oak woodlands in Portugal. In: Harrison DJ, Fuller AK, Proulx G (eds) Martens and fishers (Martes) in human-altered environments: an international perspective, Springer Academic+Business Media, New York, USA

Sawada M (1999) ROOKCASE: an Excel 97/2000 Visual Basic (VB) add-in for exploring global and local spatial autocorrelation. Bull Ecol Soc Am 80:231-234

Schooley RL (2006) Spatial heterogeneity and characteristic scales of species-habitat relationships. Bioscience 56:533-537

Sidorovich V, Kruuk H, MacDonald DW (1999) Body size, and interactions between European and American mink (Mustela lutreola and M. vison) in Eastern Europe. J Zool 248:521-527

Steams SC (1976) Life-history tactics: a review of the ideas. Quart Rev Biol 51:3-47

Swihart RK, Feng Z, Slade NA, Mason DM, Gehring TM (2001) Effects of habitat destruction and resource supplementation in a predator-prey metapopulation model. J Theor Biol 210:287-303

Virgós E (2001) Relative value of riparian woodlands in landscapes with different forest cover for medium-sized Iberian carnivores. Biodiv Conserv 10:1039-1049

Virgós E (2002) Are habitat generalists affected by forest fragmentation? A test with Eurasian badgers (Meles meles) in coarse-grained fragmented landscapes of central Spain. J Zool 258:313-318

Virgós E, Casanovas JG (1998) Distribution patterns of the stone marten (Martes foina) in Mediterranean mountains of central Spain. Z Säugetierkd 63:193-199

Virgós E, Garcia FJ (2002) Patch occupancy by stone martens Martes foina in fragmented landscapes of central Spain: the role of fragment size, isolation and habitat structure. Acta Oecol 23:231-237

Virgós E, Llorente M, Cortesa Y (1999) Geographical variation in genet (Genetta genetta L.) diet: a literature review. Mammal Rev 29:117-126

Virgós E, Recio MR, Cortés Y (2000) Stone marten (Martes foina) use of different landscape types in the mountains of central Spain. Z Säugetierkd 65:375-379

Wagner HH, Fortin M-J (2005) Spatial analysis of landscapes: concepts and statistics. Ecology 86:1975-1987

White GC, Garrot RA (1990) Analysis of wildlife radio-tracking data. Academic Press, New York, p 383

Wiens JA (1976) Population responses to patchy environments. Ann Rev Ecol Syst 7:81-120

Wiens JA (1989) Spatial scaling in ecology. Funct Ecol 3:383-397

Worton BJ (1989) Kernel methods for estimating the utilization distribution in home-range studies. Ecology 70:164-168

Wu J (2004) Effects of changing scale on landscape pattern analysis: scaling relations. Lands Ecol 19:125-138

Zalewski A (2007) Does size dimorphism reduce competition between sexes? The diet of male and female pine martens at local and wider geographical scales. Acta Ther 52:237-250

Zar JH (1999) Biostatistical analysis Pearson Prentice-Hall, Upper Saddle River, NJ, USA 